\title{
Dokter Tunggu, A Hospital Application for Patient of Healthcare and Social Security Agency
}

\author{
Muhammad Riyadi ${ }^{1}$, Rhian Indradewa ${ }^{2}$, Tantri Yanuar Rahmat Syah $^{3}$, \\ Edi Hamdi ${ }^{4}$
}

${ }^{1,2,3,4}$ Department Management, Faculty Economic and Business, Esa Unggul University, Jakarta - Indonesia

Corresponding Author: Muhammad Riyadi

\begin{abstract}
PT. Zaps Technology is a company engaged in technology and information by producing application products with the name Dokter Tunggu (Doku). The application was created to eliminate queues that often occur in Healthcare and Social Security Agency patient services at level I Hospitals and Health Facilities. Place of company at Bekasi Jawa Barat, The location is said to be chosen because Bekasi is one of the supporting areas for the capital city and has a variety of complete business facilities. This company's strategy is to create innovations in Healthcare and Social Security Agency patient services where the application made has various features that are able to eliminate queues.

The application has an online referral menu on the application so that Hospitals, Level I Facilities and Healthcare and Social Security Agency patients are easier to take advantage of BPJS services. The waiting doctor application will display real time conditions at the referral hospital so that BPJS users can monitor the condition of BPJS services at the destination Hospital.
\end{abstract}

Keywords: Dokter Tunggu, Hospital, Online Sevice, Business Planning.

\section{INTRODUCTION}

Healthcare and Social Security Agency is a government service center that was formed to organize the National Health Insurance which does not escape the queue problem. Being a mandatory BPJS participant for workers in the formal and informal sectors, the number of participants in the National Health Insurance program organized by BPJS Health reached 222.5 million people as of December 31, 2020. Based on interviews conducted with 20 respondents who used Healthcare and Social Security Agency services in found that the problem that is often faced by patients is the queue that is often experienced when using Healthcare and Social Security Agency services. The level I facilities used were 10 people using the Clinic, 11 people stated that queues were the main obstacle in Healthcare and Social Security Agency services and eight people stated that on existing facilities, as many as 12 people stated that the cause of the queues was in the filing process. In addition, two respondents stated that because of the large number of patients who came, the queues grew longer. For the time spent by the agency patients, 14 respondents took more than 30 minutes to get the agency services, while six respondents took less than 30 minutes.

\section{MATERIALS AND METHODS a. QSPM Analysis}

QSPM calculation is based on input from internal external matrix weights, as well as alternative strategies at the matching stage. In concept, QSPM is used to determine the relative attractiveness of various strategies based on an analysis of how far internal and external success factors are utilized. The QSPM analysis for the strategy that will be implemented by DOKU 
Muhammad Riyadi et.al. Dokter Tunggu, a hospital application for patient of healthcare and social security agency.

can be seen in the QSPM analysis table below:

Tabel 1.1. Quantitive Strategic Planning Matrix Analysis

\begin{tabular}{|c|c|c|c|c|c|}
\hline \multirow[t]{2}{*}{ Key Factor } & \multirow[t]{2}{*}{ Weight } & \multicolumn{2}{|c|}{$\begin{array}{l}\text { Product } \\
\text { Development }\end{array}$} & \multicolumn{2}{|c|}{$\begin{array}{l}\text { Market } \\
\text { Penetration }\end{array}$} \\
\hline & & AS & TAS & AS & TAS \\
\hline \multicolumn{6}{|l|}{ Opportunities } \\
\hline $\begin{array}{l}\text { Regulation about healthcare service is mandatory to give } \\
\text { the best service }\end{array}$ & 0,04 & 3 & 0,12 & 4 & 0,16 \\
\hline $\begin{array}{l}\text { Government create Healthcare and Social Security } \\
\text { Agency }\end{array}$ & 0,02 & & & 3 & 0.06 \\
\hline Regulation of customer protection & 0,05 & 2 & 0,10 & & \\
\hline Budget of state budget increases & 0,04 & 2 & 0,08 & 4 & 0,16 \\
\hline $\begin{array}{l}\text { Users of Healthcare and Social Security Agency is } 83 \% \\
\text { of total population of Indonesia }\end{array}$ & 0,12 & & & 3 & 0,36 \\
\hline $\begin{array}{l}\text { Satisfaction level to Healthcare and Social Security } \\
\text { Agency increases }\end{array}$ & 0,03 & 3 & 0,09 & 2 & 0,06 \\
\hline Healthcare insurance users increases & 0,10 & 4 & 0,40 & 4 & 0.40 \\
\hline $\begin{array}{l}\text { There is a queue that is quite time-consuming at some } \\
\text { health insurances }\end{array}$ & 0,06 & 3 & 0,18 & 4 & 0.24 \\
\hline Internet conditions are improving & 0,06 & 2 & 0,12 & & \\
\hline Internet users are increasing & 0,15 & & & & \\
\hline $\begin{array}{l}\text { People trust consultation with hospital health workers } \\
\text { more than with health application services }\end{array}$ & 0,02 & & & & \\
\hline Integrated Hospital Management Information System & 0.03 & & & & \\
\hline
\end{tabular}

Continued Quantitative Strategic Planning Matrix Analysis

\begin{tabular}{|c|c|c|c|c|c|}
\hline \multirow[t]{2}{*}{ Key Factor } & \multirow[t]{2}{*}{ Weight } & \multicolumn{2}{|c|}{$\begin{array}{l}\text { Product } \\
\text { Development }\end{array}$} & \multicolumn{2}{|c|}{$\begin{array}{l}\text { Market } \\
\text { Penetration }\end{array}$} \\
\hline & & AS & TAS & AS & TAS \\
\hline \multicolumn{6}{|l|}{ Threats } \\
\hline $\begin{array}{l}\text { Standard regulations for health services, especially } \\
\text { Healthcare and Social Security Agency, are constantly } \\
\text { changing }\end{array}$ & 0,1 & 4 & 0.48 & 2 & 0,24 \\
\hline $\begin{array}{l}\text { People aged } 50 \text { years and over still have difficulty using } \\
\text { mobile-based applications }\end{array}$ & 0,06 & 3 & 0,18 & 1 & 0,06 \\
\hline $\begin{array}{l}\begin{array}{l}\text { Socio-cultural shift from traditional consultation to } \\
\text { teleconsultation }\end{array} \\
\end{array}$ & 0,02 & & & 2 & 0,04 \\
\hline $\begin{array}{l}\text { The Healthcare and Social Security Agency application is } \\
\text { not yet perfectly connected to Hospital Management } \\
\text { Information System }\end{array}$ & 0,10 & 4 & 0,24 & 3 & 0,18 \\
\hline & 1 & & & & \\
\hline \multicolumn{6}{|l|}{ Strengths } \\
\hline Network & 0,2 & 4 & 0.08 & 1 & 0,02 \\
\hline Product Innovation & 0,05 & 2 & 0,10 & 2 & \\
\hline Quality and Feature & 0,1 & & & 3 & 0,03 \\
\hline IT Experts & 0,05 & 4 & 0,20 & & \\
\hline Culture & 0,08 & 2 & 0.16 & & \\
\hline Technology and Patents & 0,18 & & & & \\
\hline Physical & 0,03 & & & & \\
\hline \multicolumn{6}{|l|}{ Weaknesses } \\
\hline Unpopular product & 0,06 & 3 & 0,18 & & \\
\hline Unpopular partnership & 0,07 & 4 & 0,28 & & \\
\hline Financial & 0,11 & 3 & 0,33 & 4 & 0,44 \\
\hline Human Skill & 0,01 & & & & \\
\hline Price & 0.06 & & & & \\
\hline Total & 1 & & 3.32 & & 2,45 \\
\hline
\end{tabular}


Muhammad Riyadi et.al. Dokter Tunggu, a hospital application for patient of healthcare and social security agency.

\section{b. Lean Canvas Model}

Table 1.2. Lean Canvas Model

\begin{tabular}{|c|c|c|c|c|}
\hline $\begin{array}{l}\text { - Long queue at } \\
\text { the hospital } \\
\text { - Referrals are still } \\
\text { manual/written } \\
\text { letters } \\
\text { - Patients for } \\
\text { treatment and } \\
\text { referrals are still } \\
\text { mixed because the } \\
\text { system is still } \\
\text { manual }\end{array}$ & $\begin{array}{l}\text { - Eliminate queues } \\
\text { because the system } \\
\text { is online } \\
\text { - online referral } \\
\text { - Referral patients } \\
\text { and treatment are } \\
\text { confirmed online }\end{array}$ & $\begin{array}{l}\text { Unique Value } \\
\text { Proposition } \\
\text { Business to } \\
\text { Business: } \\
\text { - Applications that } \\
\text { make The Healthcare } \\
\text { and Social Security } \\
\text { Agency services } \\
\text { easier are } \\
\text { - Level I/clinic health } \\
\text { facilities are } \\
\text { integrated online with } \\
\text { the hospital } \\
\text { - Online referrals so } \\
\text { that The Healthcare } \\
\text { and Social Security } \\
\text { Agency services in } \\
\text { hospitals are } \\
\text { monitored online } \\
\text { High Level Concept } \\
\text { - Helping hospitals in } \\
\text { reducing queues }\end{array}$ & $\begin{array}{l}\text { - The features in } \\
\text { the application } \\
\text { with Real Time } \\
\text { conditions at the } \\
\text { hospital will } \\
\text { improve hospital } \\
\text { services }\end{array}$ & $\begin{array}{l}\text { - Hospital } \\
\text { Early Adopters } \\
\text { - Reduce queues } \\
\text { at private } \\
\text { hospitals } \\
\text { - Hospitals all } \\
\text { over Indonesia }\end{array}$ \\
\hline \multicolumn{3}{|c|}{$\begin{array}{l}\text { Key Metrics } \\
\text {-Cooperation with hospitals after obtaining business licenses and } \\
\text { products } \\
\text {-The first health facility that becomes the target of the document } \\
\text { was the hospital } \\
\text {-Target for the first } 6 \text { months } 15 \text { hospitals } \\
\text {-Target of } 1 \text { year for } 33 \text { hospitals } \\
\text {-Doku will continue to innovate and maintain product service } \\
\text { quality }\end{array}$} & \multicolumn{2}{|c|}{$\begin{array}{l}\text { Channels } \\
\text {-Marketing to private hospitals and } \\
\text { Government hospitals } \\
\text {-Hospital association }\end{array}$} \\
\hline \multicolumn{2}{|c|}{$\begin{array}{l}\text { Cost Structure } \\
\text { - Marketing Cost } \\
\text { - Operational Cost } \\
\text { - Human Resource Cost }\end{array}$} & \multicolumn{3}{|l|}{$\begin{array}{l}\text { Revenue St } \\
\text {-Applicatior } \\
\text {-Website Ho } \\
\text {-Feature Sal } \\
\text {-Pop up Ads }\end{array}$} \\
\hline
\end{tabular}

\section{RESULT}

\section{a. Marketing Objective}

Vision and mission of Doku, which are to become a service company in the field of Information Technology that is full of innovation and at the forefront of Indonesia. Product development is the main strategy chosen by Doku to achieve the following marketing objectives:

Table 3.1. Marketing Objectives of Doku

\begin{tabular}{|l|l|l|l|}
\hline NO & SHORT-TERM GOALS(<1 YEAR) & MID-TERM GOALS(1-5 YEAR) & LONG-TERM GOALS(>5 YEAR) \\
\hline $\mathbf{1 .}$ & $\begin{array}{l}\text { Maintaining a relational relationship with } \\
\text { hospital decision makers }\end{array}$ & $\begin{array}{l}\text { Improving relational relationships } \\
\text { with hospital decision makers }\end{array}$ & Having own business network \\
\hline $\mathbf{2 .}$ & Creating innovative B2B digital marketing tools & Creating high value for the hospital & $\begin{array}{l}\text { Maintaining and improve innovative } \\
\text { digital marketing tools }\end{array}$ \\
\hline 3. & $\begin{array}{l}\text { Creating relationships with associations and } \\
\text { networks belonging to the target hospital }\end{array}$ & Creating high trust in the hospital & $\begin{array}{l}\text { Maintaining and improve relationships } \\
\text { with hospital decision makers }\end{array}$ \\
\hline
\end{tabular}

\section{b. Marketing Goals}

To support the achievement of marketing objectives, Doku will determine marketing targets as an indicator of the success of establishing a product development strategy with a QSPM analysis which is concluded by the following table : 
Muhammad Riyadi et.al. Dokter Tunggu, a hospital application for patient of healthcare and social security agency.

Table 3.2 Marketing Target of Doku

\begin{tabular}{|l|l|l|l|}
\hline No & Period of Time & Marketing Target & Activities \\
\hline $\mathbf{1 .}$ & $\begin{array}{l}\text { Short Term } \\
(<1 \text { Year })\end{array}$ & $\begin{array}{l}\text { Creating high value in front of hospital } \\
\text { decision makers }\end{array}$ & $\begin{array}{l}\text { Submit a proposal containing the purpose, value and benefits of } \\
\text { Doku to be presented } \\
\text { Do a presentation on the benefits and value of Doku for hospitals } \\
\text { Provide the necessary benefits for the hospital }\end{array}$ \\
\hline $\mathbf{2 .}$ & $\begin{array}{l}\text { Mid Term } \\
(1-5 \text { Year })\end{array}$ & $\begin{array}{l}\text { Creating trust in values and improving } \\
\text { relationships with the hospital }\end{array}$ & $\begin{array}{l}\text { Sales monitor and provide reports on the need or problems using } \\
\text { Doku } \\
\text { Conduct research in the form of distributing questionnaires to the } \\
\text { hospital } \\
\text { Sales take an intense approach to the decision makers }\end{array}$ \\
\hline $\mathbf{3 .}$ & $\begin{array}{l}\text { Long Term } \\
\text { (>5 Year) }\end{array}$ & $\begin{array}{l}\text { Hospitals and their networks are } \\
\text { permanent networks Doku }\end{array}$ & $\begin{array}{l}\text { Follow any personal activities invited by hospital decision makers } \\
\text { Hold regular meetings regarding Doku, hospitals, associations and } \\
\text { their networks }\end{array}$ \\
\hline
\end{tabular}

\section{c. Segmenting}

Doku's market segmentation is based on the problems faced by patients and the customer segment based on the table Lean Canvas Model by considering market segmentation based on various classifications of hospitals in Indonesia.

Table 3.3. Hospital Classification

\begin{tabular}{|l|l|}
\hline $\begin{array}{l}\text { Hospital } \\
\text { Classification }\end{array}$ & Description \\
\hline By Type & $\begin{array}{l}\text { Types A, B, C, D and E Based on the Regulation of the Minister of Health of the Republic of Indonesia Number } \\
986 / \text { Menkes/Per/1 1/1992 }\end{array}$ \\
\hline By Ownership & Government hospitals and private hospitals \\
\hline By Kinds & General hospital and special hospital \\
\hline By Length of Stay & Short-term care hospital and long-term care hospital \\
\hline $\begin{array}{l}\text { By Education } \\
\text { Affiliation }\end{array}$ & Teaching hospital and non-educational hospital \\
\hline
\end{tabular}

\section{d. Targeting}

After grouping the market segmentation, Doku determines the target market by selecting a more specific potential customer based on the customer segment listed based on the Lean Canvas Model table which is then determined that the selection of Doku's target market targets the type of private hospital based on ownership.

\begin{tabular}{|l|l|l|l|}
\hline $\begin{array}{l}\text { Hospital } \\
\text { Target }\end{array}$ & Classification & Explanation 3.4. Targeting & Reason \\
\hline $\begin{array}{l}\text { Private } \\
\text { Hospital }\end{array}$ & $\begin{array}{l}\text { By } \\
\text { Ownership }\end{array}$ & $\begin{array}{l}\text { A hospital managed by a legal entity with the aim of } \\
\text { making a profit in the form of a PT or a limited } \\
\text { liability company }\end{array}$ & $\begin{array}{l}\text { Not bound by government policies because most } \\
\text { government hospitals already use competitor } \\
\text { products }\end{array}$ \\
\hline
\end{tabular}

\section{e. Positioning}

Value propositions are things that attract or benefit from the business, and why customers buy or use them (Ambari et al., 2020). The added values depict the advantage of the product that is promoted by the company (Arifin, et al., 2019). The positioning applied by Doku refers to the Unique Value Proposition listed in the Lean Canvas Model table, namely placing Doku's Advantage Differentiation position with its competitors with the following explanation:

1. Doku provides online media on tiered referrals to enjoy Healthcare and Social Security Agency services for its patients, making it easier for these patients to get health services.
2. The document shows real time conditions in hospital services or health facilities which will detect Healthcare and Social Security Agency patients so that queues can be minimized even though there are quite a lot of participants in a day at the hospital or health facility.

3. The document shows real time conditions in hospital services or health facilities which will detect Healthcare and Social Security Agency patients so that queues can be minimized even though there are quite a lot of participants in a day at the hospital or health facility. 

agency.

4. Ease of preparing documents by uploading the required documents in the form of soft copies in Doku which is already connected online at health facilities

5. With online filing and real time conditions on hospital services or health facilities obtained by patients, this will reduce the queues that occur.

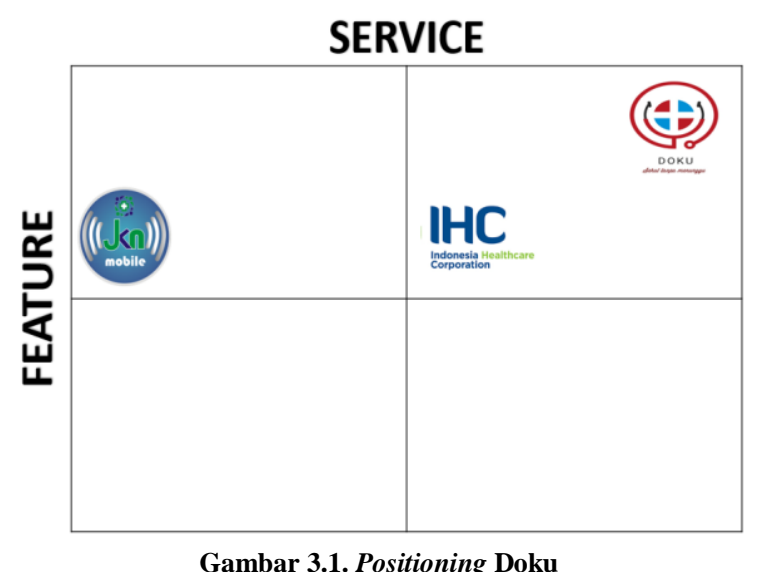

\section{Marketing Mix}

Doku is a business to business (B2B) company that sells applications to eliminate queues and sells it to hospitals. Therefore, the marketing mix used by Doku is to use the NICE method which is based on the Value Proposition listed in the Lean Canvas Model table which contains information about Doku's value which is then conveyed to customers or business partners using the mix tool. NICE marketing or Networking, Interaction, Common Interest and Experience.

\section{Networking}

There is a realization tha there is no business that runs alone in carrying out a business activity, certainly needed by partners (Ambari, et al., 2020). (In accordance with the Lean Canvas Model channel table, Doku will focus on building a network with a personal or two-way interaction approach to decision makers such as owners for private hospitals or the board of directors for government hospitals to place Doku products in their hospitals. In the beginning to build a network with hospitals, the sales division will submit a proposal that contains the goals, values and benefits of Doku. If the recipient is not the direct decision maker, the proposal will be submitted to the hospital procurement party which is then forwarded to the hospital IT division. The IT Division will consider the proposal to be submitted as a presentation material which will also be attended by decision makers.

Doku will also assign the sales division to create relationships and interactions with all levels of decision makers. However, the beginning of building a relationship with the hospital will be carried out directly by the entire board of directors of Doku who will participate in several important events organized by the target hospital intensely. In each of these important events, Doku will meet and communicate directly with representatives from the hospital to get their attention. Doku's board of directors took the initiative to build strong communication with the hospital. After several important hospital events are attended, then these will be replaced by Doku representatives from the sales division who in addition to establishing and maintaining relationships with the hospital, they also have to make reports on the progress of the relationship.

In addition, the sales division will monitor and report any needs or complaints from decision makers. This report will then be used as input for Doku. At the end of each month, the Doku application will also feature conducting research to customer hospitals in the form of distributing questionnaires. This is done in order to maintain satisfaction with the services provided by Doku.

Furthermore, Doku will also establish relationships with hospital associations and networks. This is intended to build Doku's own strong business network. One of the ways that Doku will do this is to hold a meeting with the association or network. This meeting aims to find out the problems that occur within the association or hospital network so that Doku 
can participate in providing solutions or assistance.

\section{Interaction}

Based on the customer segment of the Lean Canvas Model table, the interaction that Doku does is a presentation after making a "friend" approach to the main customer, namely the hospital. In their interactions, there are hospital parties whom Doku will take good care of, namely shareholders/owners/board of directors, associations and hospital networks. Even in his presentation, Doku will involve the hospital parties so that all hospital circles must be touched by Doku.

After the proposal is approved by the hospital's IT and procurement department, then Doku will present the product. In the presentation, Doku's board of directors will introduce Doku's functions, features and advantages. However, Doku's presentation will emphasize the value Doku has in solving problems experienced by the hospital.

After making a presentation, Doku will conduct a virtual demo to further convince the hospital about the Doku application to solve the problems they have. The virtual demo is a trial or trial whose implementation will last for a week.

\section{Common Interest}

In accordance with the customer segment listed in the Lean Canvas Model table, Doku will try to fulfill the interests of the hospital. For hospitals where the decision maker is the owner, Doku will not charge for the procurement of a virtual demo of the Doku application for a week. In addition, Doku provides discounts for certain features if the hospital has been a Doku customer for a long time.

Meanwhile, for hospitals led by the board of directors, Doku will enter into a fee agreement to the board of directors in the form of hospital benefits which will be stated in the purchase contract if the hospital he leads uses Doku in addition to personal interaction.

The hospital will also get free services in the form of making banners or banners for every event they organize. Doku will also help as a donor in organizing events such as mass vaccine events organized by government hospitals for the wider community.

The cost to build a network with the hospital will not only focus on the owners or directors, but the staff and doctors below it will also get a fee so that the delivery of information about Doku can actually reach the patient clearly. To maintain an intense relationship with the hospital, Doku will send a representative from the sales division to make the necessary reports to the company.

In terms of products, Doku will also emphasize its value to provide solutions to the hospital for every problem it has.

\section{Experience}

In accordance with the Value Proposition listed in the Lean Canvas Model table, the experience that has been instilled in the hospital has been provided since the virtual demo of the Doku application for 7 days. From the virtual demo experience, the hospital felt the benefits and value of solving the problems they had for free. If the hospital is satisfied that the Doku application can solve their problem, then the Doku and the hospital can make a deal for the Doku purchase transaction.

The experience given to the hospital does not end there. Doku, through its sales, will provide after sales services in charge of monitoring and reporting on application usage in each hospital. With this, Doku can improve and improve its services to the fullest. With this maximized after sales service, Doku hopes that the hospital will be satisfied and can extend the purchase period and Doku himself will get his own strong business network. 
Muhammad Riyadi et.al. Dokter Tunggu, a hospital application for patient of healthcare and social security agency.

\begin{tabular}{|c|c|c|}
\hline NICE & Planning and Activity & Result \\
\hline Network & $\begin{array}{l}\text { Building networks by approaching personal or two-way interactions with decision makers } \\
\text { Making a business proposal } \\
\text { Visiting hospital decision makers directly by Doku directors } \\
\text { Assigning the sales division to create relationships and interactions with all levels of } \\
\text { decision makers } \\
\text { Assigning the sales division to create relationships and interactions with all levels of } \\
\text { decision makers. } \\
\text { Maintaining relationships with hospital associations and networks }\end{array}$ & 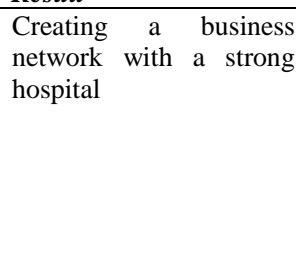 \\
\hline Interaction & $\begin{array}{l}\text { Presenting Doku } \\
\text { DoingVirtual demo Doku }\end{array}$ & $\begin{array}{l}\text { Introducing and motivate } \\
\text { the hospital to buy Doku }\end{array}$ \\
\hline $\begin{array}{l}\text { Common } \\
\text { Interest }\end{array}$ & $\begin{array}{l}\text { Eliminating fees for procurement of virtual demo } \\
\text { Cuting the price of some features } \\
\text { Holding fee agreements in the form of benefits } \\
\text { Providing free service } \\
\text { Assisting with hospital events }\end{array}$ & $\begin{array}{l}\text { Knowing and uniting the } \\
\text { interests of both parties }\end{array}$ \\
\hline Experience & $\begin{array}{l}\text { Asking for the hospital's final decision } \\
\text { Providing after-sales consultation and service }\end{array}$ & $\begin{array}{l}\text { The hospital deals with } \\
\text { buying the Doku app }\end{array}$ \\
\hline
\end{tabular}

\section{SALES}

\section{Sales and Marketing Activity}

Doku sales are based on the customer segment of the Lean Canvas Model table, namely hospitals. In the current era of technology, the community is greatly helped by the existence of various kinds of applications that facilitate their business (Rahmat, et al., 2019). Doku sales have several objectives, namely to create and maintain a "friend" relationship with the hospital, starting from doctors, staff, associations, networks to hospital decision makers. The first thing Doku sales will do is prepare a proposal that contains the goals, values and benefits of Doku to the hospital. However, most hospital decision makers will not directly accept business proposals from their external parties but rather the hospital procurement department. In order to increase customer value, it is necessary to consider policies to maintain trust such as honesty, virtue and competence (Iqbal, et al., 2020). After being accepted by the procurement department and continued to the IT department, they will assess the feasibility of the proposal which is then used as presentation material. This proposal submission phase will be easier when Doku has a network of relationships that also have a relationship with the hospital because of the bond and trust in Doku.

\section{Sales and Marketing Budget}

The following is a table of budgets for Doku's sales and marketing:

Table 3.6: Budget Sales and Marketing

\begin{tabular}{|c|c|c|c|c|c|}
\hline \multicolumn{6}{|l|}{ Description } \\
\hline Year & 1 & 2 & 3 & 4 & 5 \\
\hline Targeted Hospital & 35 & 35 & 25 & 25 & 25 \\
\hline \multicolumn{6}{|l|}{ Relational Marketing } \\
\hline Benefit for Hospital & $300,000,000$ & $450,000,000$ & $630,000,000$ & $756,000,000$ & $900,000,000$ \\
\hline Business Activity & $200,000,000$ & $330,000,000$ & $423,000,000^{\top}$ & $504,000,000$ & $612,500,000$ \\
\hline Presentation Exhibition & $60,000,000$ & $97,500,000^{\top}$ & $97,500,000$ & $147,000,000$ & $187,500,000^{\circ}$ \\
\hline Ads & $50,000,000$ & $60,000,000$ & $60,000,000$ & $97,500,000$ & $97,500,000$ \\
\hline Research & 500,000 & $1,125,000$ & $1,800,000$ & $2,625,000$ & $5,000,000$ \\
\hline Trial of Doku & $40,000,000$ & $40,000,000$ & $81,000,000$ & $105,000,000$ & $105,000,000$ \\
\hline Network Meeting & $75,000,000$ & $135,000,000$ & $171,000,000]$ & $210,000,000$ & $275,000,000$ \\
\hline Return on Relationship & $125,000,000$ & $194,400,000$ & $194,400,000$ & $304,000,000$ & $375,000,000$ \\
\hline Official Travel & $15,000,000$ & $25,000,000$ & $30,000,000$ & $40,000,000$ & $50,000,000$ \\
\hline \multicolumn{6}{|l|}{ Digital Mhrketing } \\
\hline SEM & $11,000,000$ & $11,000,000$ & $12,000,000$ & $13,000,000$ & $13,000,000$ \\
\hline Website, Email and Social Media & $44,000,000$ & $45,000,000$ & $49,000,000$ & $49,000,000$ & $50,000,000$ \\
\hline Digital Ads & $15,000,000$ & $17,000,000$ & $19,000,000$ & $21,000,000$ & $24,000,000$ \\
\hline Total & $935,500,000$ & $1,406,025,000$ & $1,768,700,000$ & $2,249,125,000$ & $2,694,500,000$ \\
\hline
\end{tabular}


Muhammad Riyadi et.al. Dokter Tunggu, a hospital application for patient of healthcare and social security agency.

\section{INCOME STREAM \\ Income Planning}

Based on the Lean Canvas Model table, Doku's revenue stream other than from sales applications, there are several other revenue streams such as web hosting, help desk, application installation and e-payments. The following is a revenue planning table that consists of app sales to other Doku revenue streams.

\begin{tabular}{|c|c|c|c|c|c|}
\hline \multirow{2}{*}{\multicolumn{6}{|c|}{ 7. Income Planning }} \\
\hline & & & & & \\
\hline Year & 1 & 2 & 3 & 4 & 5 \\
\hline Targeted Hospitals & 35 & 35 & 25 & 25 & 25 \\
\hline Doku Price & \multirow{2}{*}{$\begin{array}{r}120,000,000 \\
4,200,000,000\end{array}$} & \multirow{2}{*}{$\begin{array}{r}120,000,000 \\
4,200,000,000\end{array}$} & \multirow{2}{*}{$\begin{array}{r}120,000,000 \\
3,000,000,000\end{array}$} & \multirow{2}{*}{$\begin{array}{r}120,000,000 \\
3,000,000,000\end{array}$} & \multirow{2}{*}{$\begin{array}{r}120,000,000 \\
3,000,000,000\end{array}$} \\
\hline Income from Application & & & & & \\
\hline \multicolumn{6}{|c|}{ Revenue Stream } \\
\hline Hosting Web & & \multirow[t]{4}{*}{$1,500,000,000$} & \multirow{4}{*}{$\begin{array}{r}5,062,500,000 \\
1,080,000,000 \\
37,500,000\end{array}$} & \multirow{4}{*}{$\begin{array}{c}9,639,000,000 \\
1,680,000,000 \\
63,000,000\end{array}$} & $14,250,000,000$ \\
\hline Help Desk & & & & & $2,375,000,000$ \\
\hline Application Installment & & & & & $87,500,000$ \\
\hline E-payment & & & & & $375,000,000$ \\
\hline Total & $4,200,000,000$ & $5,700,000,000$ & $9,180,000,000$ & $14,382,000,000$ & $20,207,500,000$ \\
\hline
\end{tabular}

\section{Net Marketing Contribution (NMC)}

Doku needs the right measuring tools to measure the effectiveness of planning on its financial statements. NMC is calculated by means of total revenue minus the sales and marketing budget which can be seen in the following table:

\begin{tabular}{|c|c|c|c|c|c|}
\hline \multirow{2}{*}{\multicolumn{6}{|c|}{ Description }} \\
\hline & & & & & \\
\hline Year & 1 & 2 & 3 & $\overline{4}$ & $\overline{5}$ \\
\hline Total of Income & $4,200,000,000$ & $5,700,000,000$ & $9,180,000,000$ & $1,438,200,000$ & $20,207,500,000$ \\
\hline Total of Marketing Cost & $935,500,000$ & $1,406,025,000$ & $1,768,700,000$ & $2,249,125,000$ & $2,694,500,000$ \\
\hline Net Marketing Contribution & $3,264,500,000$ & $4,293,975,000$ & $7,411,300,000$ & $(810,925,000)$ & $17,513,000,000$ \\
\hline
\end{tabular}

\section{CONCLUSION}

PT. Zaps Technology is a business planning concept that is engaged in information technology by producing an application / software product with the name Doctor Wait (Doku). This application is used by Hospitals and Clinics as satellites to serve BPJS patients to make it easier to use BPJS services. Based on the QSPM calculations above, it can be concluded that PT. Zaps Technology with its product Doctor Wait has a product development strategy, with the results of this calculation, the various innovations that accompany this application need to be improved and developed so that they are able to serve the needs in the health sector well and thoroughly. In financial planning, the Doctor Wait application has an IRR of $34 \%$ then a payback period of 2 years 5 months and has an NPV value of Rp. $10,158,478,730$,- From the calculation it can be concluded that the investment in PT. Zaps Technology with Doctor Wait products is very interesting and can be considered and taken into account for investment.

\section{Acknowledgement: None}

Conflict of Interest: None 

agency.

\section{Source of Funding: None}

\section{REFERENCES}

1. Ambari, A.K., Syah, T. Y. R., Indradewa, R., \& Pusaka, S. (2020). Marketing Strategy and Business Canvas at Jeeva Works Corporation. Journal of Multidisciplinary Academic. 4 (2).

2. Arifin, F.A.S., Syah, T. Y. R., Indradewa, R., \& Pusaka, S. (2019). Sales and Marketing Strategies Duck Nugget Product Using Porter's Five Force and SWOT Analysis. Journal of Multidisciplinary Academic. 3(4).

3. Fred, R. D., \& Forest, R. D. (2016). Strategic Management: a Competitive Advantage Approach, Concepts, Global Edition. In The Decision Stage: The Quantitative Strategic Planning Matrix (QSPM) (pp. 268-270). 16th Harlow, England: Pearson Education Limited.
4. Haryanto, J.O. (2017). Beyond Marketing Growth and Sustainability. Gramedia Pustaka Utama.

5. Iqbal, M. A., Indradewa, R., Murni, Y., \& Putra, D. (2020). The Effect of Trust and Service Quality to Custom (Case Study Bluebird Taxi in Indonesia). 12 (18).

6. Rahmat, R., Syah, T. Y. R., Indradewa, R., \& Pusaka, S. (2019). The Role of Service Quality and Customer Satisfaction: A Case Study for Applications of Go-Food. Russian Journal of Agricultural and Socio-Economic Sciences. 7 (91). DOI 10. 18551/rjoas.201907.30.

How to cite this article: Riyadi M, Indradewa R, Syah TYR et.al. Dokter Tunggu, a hospital application for patient of healthcare and social security agency. International Journal of Research and Review. 2021; 8(8): 450-458. DOI: https://doi.org/10.52403/ijrr.20210861 